The procedure described is inexpensive, relatively fast, and increases the isolation rate of anaerobes, most of which are found in ulcers. A study is proposed to evaluate the clinical importance of these findings.

JANET GOODLAND Public Health Laboratory, Musgrove Park Hospital, Taunton, Somerset. TAI 5DB.

\section{Unexpected expectoration}

We would like to draw attention to the unusual appearance of a bronchial cast that first led us to believe a patient had expectorated a portion of lung during the course of a respiratory arrest, (figure).

A 58 year old man was admitted with acute chest pain and had known chronic obstructive airways and coronary artery diseases. Shortly after admission he had a respiratory arrest and during resuscitation a length of reddish brown tissue $14 \mathrm{~cm} \times 1.5 \mathrm{~cm} \times 1 \mathrm{~cm}$ was sucked from the back of the throat. It had the consistency and appearance of lung (fig la). Microscopical examination showed irregular air spaces with thin walls resembling alveoli (fig lb). The walls comprised red cells, eosinophils, and acellular eosinophilic strands. To ensure that this was not lung tissue, a reticulin stain was necessary. This confirmed the absence of any permanent structures of the alveolar wall.

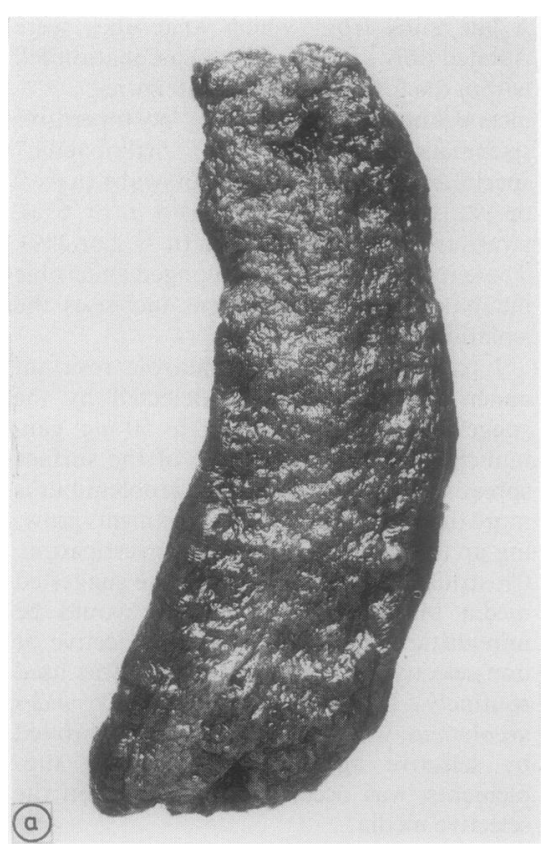

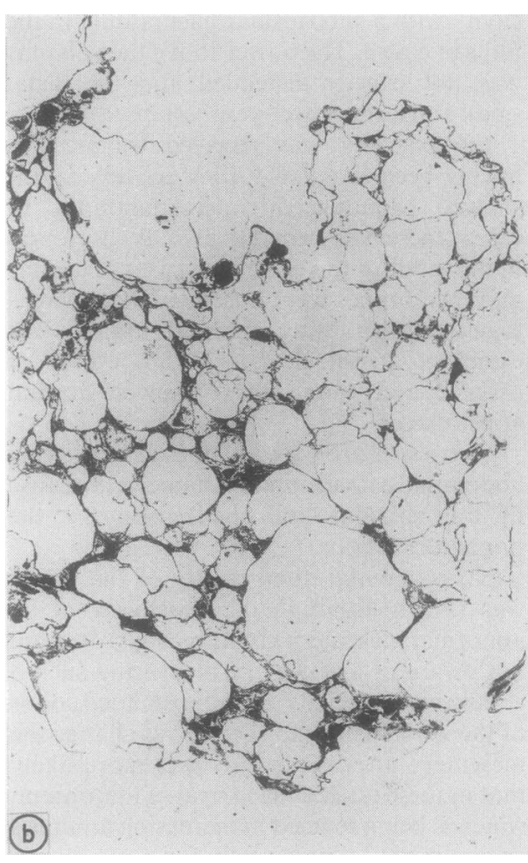

We were relieved to realise this was not lung and concluded that this was a bronchial cast "whisked" into its present "pulmonary" form by coughing. It clearly differs from the common descriptions of bronchial casts that show alternating cellular and acellular areas. The former exhibit large numbers of eosinophils, the latter are mostly mucous. CharcotLeyden crystals and Kurschmann's spirals are also common in the typical cast. Only one area was eventually found on the current case with laminated mucus strands that bore any resemblance to a typical bronchial cast.

M SUNDARESAN, AB PRICE, Department of Pathology, Northwick Park Hospital, Watford Road, Harrow, Middlesex

Non-polio enteroviruses and motor neurone disease

There is considerable interest in the possible

Table Results of Coxsackie B tests in patients and controls

\begin{tabular}{|c|c|c|c|c|c|}
\hline \multirow[b]{2}{*}{ Group } & \multirow[b]{2}{*}{ No $(\%)$ tested } & \multirow{2}{*}{$\begin{array}{l}C B \text { IgM } \\
\text { positive }\end{array}$} & \multicolumn{3}{|c|}{$C B$ neutralising antibody titres } \\
\hline & & & $\geqslant 512$ & 256 & $\geqslant 256$ \\
\hline $\begin{array}{l}\text { Patients } \\
\text { Controls* }\end{array}$ & $\begin{array}{l}17(100) \\
11(100)\end{array}$ & $\begin{array}{l}4(23 \cdot 5) \\
2(18)\end{array}$ & $\begin{array}{l}5(29) \\
1(10)\end{array}$ & $\begin{array}{l}7(41) \\
1(10)\end{array}$ & $\begin{array}{r}12(71) \\
2(20)\end{array}$ \\
\hline
\end{tabular}

viral aetiology of various neurological diș eases. The recent observation by one of (SK) of an apparent cluster of cases of mot\& neurone disease prompted us to examine the possible role of the group B Coxsackie? viruses (CBV). The putative role of $\mathrm{CBV}$ i the post-viral fatigue syndrome is current林 being evaluated by us using the $\mu$-antibody capture ELISA technique for the detection of CBV IgM antibody.' Detection of this antibody implies recent or persisting infeor tion. It is well established that this CBY ELISA test can cross react with other non-polio enteroviruses, ${ }^{23}$ thus extending its diagnostic scope.

We studied sera from 17 clinically define्त्व cases of motor neurone disease (10 me seven women, aged between 39-87 years) and 11 patients with other neurologicil disorders (seven men, four women, age between 29-64 years). All serum specimens were collected between January and March 1986 (table). There was little difference in the number of patients with motor neurone disease giving a CBV IgM positive responß compared with the control group. Using the more conventional CBV neutralising antibody assay, however, there was evidenco of a higher proportion with raised $(\geqslant 256)$ antibody titres in patients with mots neurone disease.

In evaluating these data it should pointed out that CBV was epidemic in the local community during 1985-86; this 웋 reflected by higher background titres Im CBV IgM and neutralising antibody assays. This may possibly explain the higher titres seen in our cases, but the number of patients studied was small, and the more sensitive CBV IgM assay failed to show a pronounces difference in the two groups studied.

Although the results of this preliminaly. investigation are inconclusive, we suggeft that further epidemiological studies of CB infection in patients with motor neurope disease are merited. Definitive evidence of the role of any virus in this and other neurological diseases is now feasible usimg the molecular biological techniques of in situ and Southern blot hybridisation to detect viral nucleic acid sequences in affectes neurological tissues. asymptomatic adults assessed by both the 


\author{
*PG KENNEDY, \\ †ELEANOR J BELL, \\ †SHEILA A KEANE, \\ TMORAG C TIMBURY \\ * Department of Neurology, \\ Institute of Neurological Sciences, \\ Southern General Hospital, \\ Glasgow, G5I 4TF \\ †Enterovirus Reference (Scotland) \\ Laboratory, \\ Ruchill Hospital, \\ Glasgow, G20 9NB \\ †6 Quadrant Road, \\ Glasgow, G43 \\ IDepartment of Bacteriology, \\ Royal Infirmary, \\ Glasgow, G4 OSF
}

1 McCartney RA, Banatvala JE, Bell EJ. Routine use of $\mu$-antibody-capture ELISA for the serological diagnosis of Coxsackie B virus infections. J Med Virol 1986;19:205-12.

2 Pugh SF. Heterotypic reactions in a radioimmunoassay for Coxsackie B virus specific IgM. J Clin Pathol 1984;37:433-9.

3 Bell EJ, McCartney RA, Basquill D, Chaudhuri AKR. $\mu$-Antibody capture ELISA for the rapid diagnosis of enterovirus infections in patients with aseptic meningitis. J Med Virol 1986;19:213-7.

Cytopathic effects of Campylobacter pylori urease

It is now accepted that there is a close association between Campylobacter pylori and gastroduodenal disease, ${ }^{12}$ but the precise nature of the association remains unclear, and the potential pathogenic role of the organism requires investigation. Many possible virulence mechanisms merit consideration including direct toxic effects of bacterial products on cells. We investigated the action of bacteria free preparations derived from $C$ pylori on cell cultures and obtained evidence that urease may play an important part in cell damage.

Three isolates of $C$ pylori from gastric antral biopsy specimens from separate patients in this hospital were used. Organisms were grown on $10 \%$ blood agar for 48 hours, suspended in phosphate buffered

Table Titres of cytopathic effects produced by $C$ pylori preparations after 20 hours' incubation with Vero cells under different conditions

\section{Additions}

\begin{tabular}{|c|c|c|c|}
\hline Test preparation & $\overline{N i l}$ & $30 \mathrm{mM}$ urea & $30 \mathrm{mM}$ urea + serum ${ }^{*}$ \\
\hline $\begin{array}{l}\text { Cpylori } 1 \\
C \text { pylori } 2 \\
C \text { pylori } 3\end{array}$ & No cytopathic effect & $\begin{array}{l}1: 384 \\
1: 48 \\
1: 384\end{array}$ & $\begin{array}{l}1: 96 \\
1: 12 \\
1: 96\end{array}$ \\
\hline
\end{tabular}

*added at 1:32 final dilution. saline, and centrifuged at $7000 \mathrm{~g}$ for 20 minutes. The supernatants were filtered using a $0 \cdot 2 \mu \mathrm{m}$ filter and applied to established Vero cell monolayers. Cytopathic effects were then observed. ${ }^{3}$

None of the three preparations produced a clearly discernible cytopathic effect after incubation with cells over 96 hours, but when urea was added to the system $(30 \mathrm{mmol} / \mathrm{l})$, the cells rounded up within 90 minutes (table) and subsequently lysed. These effects were accompanied by a pronounced rise in $\mathrm{pH}$. The three $C$ pylori preparations contained urease, and similar cytopathic effects were obtained using Jack bean and Bacillus ureases (Sigma) in the presence of urea. A two-fold dilution series of ammonia added directly to cell monolayers resulted in the same characteristic cytopathic effect at final concentrations of $1.35 \mathrm{mmol} / \mathrm{l}$ and above. If the ammonia was pre-neutralised to give a $\mathrm{pH}$ of 7.4 the cytopathic effect was retained at concentrations of $2.7 \mathrm{mmol} / \mathrm{l}$ and above. Raising the $\mathrm{pH}$ using $\mathrm{NaOH}$ produced an entirely different cytopathic effect. These findings support the view that the cytopathic effect produced by the $C$ pylori preparations was related to the generation of ammonia by ureolytic activity and that this effect was largely independent of $\mathrm{pH}$.

The cytopathic activity of our preparations withstood a temperature of $56^{\circ} \mathrm{C}$ for 15 minutes but was abolished at $80^{\circ} \mathrm{C}$. Under the conditions used this activity was not affected by the addition of the competitive urease inhibitor thiourea, which, in contrast, did inhibit the cytopathic effect produced by the commercially available purified ureases. The addition of serum from a patient colonised with $C$ pylori and with high titres of circulating antibodies against the organism, determined by ELISA ${ }^{4}$ caused a substantial reduction in cytopathic effect titre (table). This serum had no analogous neutralising effect on the two commercially obtained ureases.

Our findings suggest that the urease activity of $C$ pylori can cause cytopathic effects by the production of ammonia. Although other workers have suggested an important role for urease $^{5}$ we have shown

directly the cytopathic potential of this activity. As we have also shown that concentrations of ammonia as low as $2.7 \mathrm{mmol} / \mathrm{l} \mathrm{can}$ produce clear cytopathic effect even at physiological $\mathrm{pH}$, it is likely that local ammonia production by this organism is sufficient to produce cell damage and result in inflammation. We conclude that the ureolytic activity of $C$ pylori may be important in the pathogenesis of gastritis and peptic ulcer.

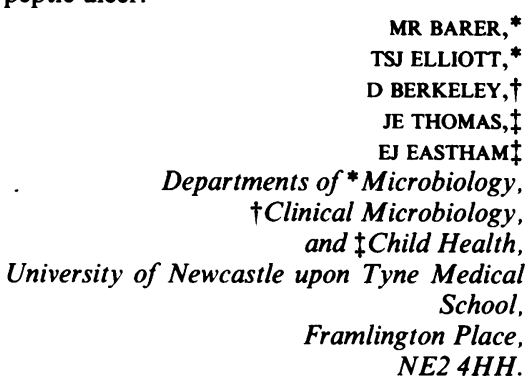

References

1 Marshall BJ. Campylobacter pyloridis and gastritis. J Infect Dis 1986;53:650-7.

2 Graham DY, Klein PD. Campylobacter pyloridis gastritis: the past the present and speculations about the future. Am J Gastroenterol 1987;82:283-6.

3 Barer MR, Millership SE, Tabaqchali S. Relationship of toxin production to species in the genus Aeromonas. J Med Microbiol 1986;22:303-9.

4 Jones DM, Eldridge J, Fox AJ, et al. Antibody to the gastric campylobacter-like organism ("Campylobacter pyloridis")-Clinical correlations and distribution in the normal population. J Med Microbiol 1986;22:57-62.

5 Hazell SL, Lee A. Campylobacter pyloridis, urease, hydrogen ion back diffusion and gastric ulcers. Lancet 1986;ii:15-17.

\section{Other correspondence}

\section{Brown fat and sudden death}

We were interested by the report of brown fat necrosis found in post-perinatal necropsy specimens by Stephenson and Variend.' Brown fat is a favoured substrate for various virus infections in newborn mice infected with group B Coxsackie viruses. ${ }^{2}$ Brown fat necrosis can also be produced in mice infected with some group A Coxsackie viruses, ${ }^{3}$ particularly Coxsackie A7 virus which can do so in adult cotton rats. ${ }^{4}$ It was for this 